\title{
Enhancing Student's Understanding in Entrepreneurship Through Business Plan Simulation
}

\author{
M. Guzairy ${ }^{1, *}, N$. Mohamad ${ }^{2}$, and $A . R$. Yunus ${ }^{2}$ \\ ${ }^{1}$ Faculty of Business Management, Kolej Universiti Agrosains Malaysia, Melaka, Malaysia \\ ${ }^{2}$ Faculty of Technology Management and Technopreneurship, Universiti Teknikal Malaysia, Melaka, Malaysia
}

\begin{abstract}
Business Plan is an important document for entrepreneurs to guide them managing their business. Business Plan also assist the entrepreneur to strategies their business and manage future growth. That is why Malaysian government has foster all Higher Education Provider to set entrepreneurship education as compulsory course. One of the entrepreneurship education learning outcome is the student can write effective business plan. This study focused on enhancing student's understanding in entrepreneurship through business plan simulation. This study also considers which of the factor that most facilitate the business simulation that help the student to prepare effective business plan. The methodology of this study using quantitative approach with pre-and post-research design. 114 students take part as respondent in the business simulation and answer quantitative survey pre-question and post question. The crucial findings of this study are student characteristic factor after playing the simulation contribute much on facilitate business plan learning. The result has shown that the business plan simulation can enhance undergraduate student in understanding entrepreneurship by preparing effective business plan before opening new startup.
\end{abstract}

\section{Introduction}

Bank Entrepreneur play a crucial role in economic development on Malaysia targeting to be developed country in year 2020. Various action has been implement by the government to produce more entrepreneur in this country. To expose the citizen with the entrepreneurship, most of the higher learning offer entrepreneurship programs and courses. They also fostering the student to open small business in campus. When we talk about start up a business, the main reason why people afraid to open a business is because of financial sources. Entrepreneur need to have sources of capital for business start-up, however to obtain the financial support is not easy although there are many sources of finance from local bank and government agencies. The requirement or the condition to obtain the funding is to prepare business plan. Business plan are the crucial element that will determine the amount fund that the entrepreneur eligible from the funders.

In entrepreneurship education, student need to learn how to prepare effective business plan. Business plan can be categories as a part of most important factor that can determine the business process growth and sustainability [1-3]. The need of preparing business plan often be the first criteria that will presented by the entrepreneur for get financial assistant from bankers and investors [4-5]. Nowadays entrepreneurship courses are compulsory for the most of Malaysian Higher Education Provider. They must run the Entrepreneurship Program to expose and inculcate students to the entrepreneurial skills and values, which contain of the element of leadership, creativity, innovation, competitiveness, resilience, calculated risk, independence, and able in creating and identifying the opportunities. The objective of this study is to recognize the factor and process in business plan simulation that facilitate business plan learning.

One of the element in studying entrepreneurship course is business plan that remain major objective entrepreneurship program [1]. In certain Higher Education Provider (HEP), they offer business plan as stand-alone subject and it became final year team project. The 4th issue state by the Malaysian Entrepreneurship Policy show that there are still occur lack of effectiveness of entrepreneurship and education and program. In other hand, the third element of Entrepreneurship Development Policy is to Strengthen Entrepreneurship that aim to expose students to the real world of business at the same time assisting them that decide to choose a startup business as a career. Entrepreneurship education in Malaysia Higher Education also is some of the General Subject (MPU) that was established September 2013.

\subsection{Entrepreneurial Education}

Providing entrepreneurship course as compulsory subject for undergraduate program in most of higher 
education institution will increase the figure of the student that taking entrepreneurship education. Entrepreneurship education play vital role in developing entrepreneurs however the ability to foster entrepreneurship value with traditional teaching method still unclear and the possibility still arguable [6-7]. Entrepreneurship education nowadays still deliver in traditional method in classrooms as teacher centered learning that using didactic approach and the student gain knowledge when the teacher is delivering knowledge [7-8]. In this case the knowledge transfers only occur in a single method and lack of student participant that mean lack of student centered learning. The effectiveness of an entrepreneurship education courses relies mostly on educator's skills and knowledge of different pedagogy especially entrepreneurship teaching method [9]. While Ismail and Ahmad said that in inculcating the entrepreneurial spirit for enterprises education require several innovations in the content, exposure to real work life, assessment method towards more practical and teaching mode [8]. Both discussing on teaching method that will give the effectiveness on delivering entrepreneurship education. With entrepreneurship education student, especially the undergraduates that tend to start business career will help them be prepare on every step they pick to start new enterprise.

\subsection{Business Plan Courses}

Business plan can offer a roadmap for the future and advantage potential investors to invest the growing business [10]. Business plan is one of the major courses provide in entrepreneurship education define business plan as planning process outcome [1,9]. Writing business plan enable to prepare organizations and to predict well for future challenges [2]. In an educational aspect, the business plan plays as a simulation of the process of developing a business, including: (1) confirmation of the need for a given product or service; (2) funding sources, analysis of the financial requirements and potential returns; (3) evidence of a distribution and marketing plan; and (4) evidence of a team with the talent necessary to execute the plan. It is agreed by [11] that business plan as a condition of most potential funders before deciding to invest.

\subsection{Experiential Learning}

Experiential processes such as reflection, action and conceptualization are used via pedagogy, which include or example, action learning, group work, learning contracts, and self-developme [12]. A study on experiential learning in scope of management, by Kolb has utilized Experiential Learning Theory to make decision and solve problem, strategy formulation and entrepreneurial opportunity finding (see figure 1) [13]. In determining an experiential learning product whether is a true simulation or not is assessed by the degree to which the product has external conformity

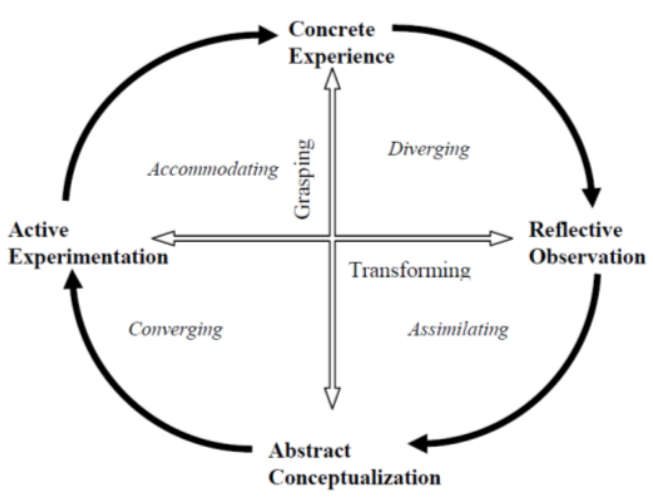

Fig.1 Experiential Learning adapt from Kolb and Kolb, 2008

and thus truly shows a real business environment. Ismail define experiential learning as a learner-centered approach that caters to individual learning styles [8]. Based on study they see that experiential learning provides students a method for adapting and developing their attitudes [14], skill and knowledge. Dellaportas and Hassall, found that to produce longterm learning outcome, experiential learning can be a powerful learning tool that can be apply in education [15]. Learning is categorized as a process, not as an outcome. To enhance learning in higher education, the primary interest should be on attracting students in a process that best improves their learning. Learning is best ease by a process that produce out the students' idea and beliefs about a topic and then they can be tested, examined, and together with new, more refined ideas. All students agreed that experiential learning is important in assisting them to build innovative skills and creative thinking [16]. Ismail and Ahmad mention that the objective of experiential learning is to develop an environment in which students actively engage with the entrepreneurial process rather than just read about it [8]. This process of experiential is representing as an idealized learning spiral or cycle where the learner thinking, reflecting experiencing, doing in a relating process that is reacted to the learning situation and what is being learned. Research showed that experiential learning contributes to enhancing students' employability and workplace readiness [17]. 


\subsection{Business Simulation}

Business Simulation courses were important to cope with the compulsion from stakeholders, but are still crucial because they show an innovative way of education. Simulation games are all quite the same in that they need input from the students, process the information and confront the participants with a certain consequence of their decisions, both in right terms of liquidity status, profit, loss, or market share, and about other virtual rivals [18]. Simulation can bring impact to the path of education, it brings the player or the participant to use their current knowledge to face the simulated business world. They tend to enhance their knowledge and skill and the same time learn new thing to stay survive. Considering management area in handling business, simulation enable player to understanding the management function in business environment. Load with experience, most of entrepreneur first knowledge is from their experience, learning by experiencing will allow student to improve their skill especially in business world. Business simulations are effective experiential method that promote business concepts, to appreciate a crossfunctional understanding of business and to increase decision-making [19]. Participate in business simulation is an experiential learning that the student can stimulate and feel. Teaching strategies that would facilitate this decision; however, current development efforts, the simulations and games to get more attention from the teaching [20]. Therefore, the team can create a social, a serious game that teaches the concept of identity in an environment of business who has multiple aspects of online communities [21]. Tao found learned that many teachers no longer use business simulation games (BSG), or assistant teacher had just asked them to do a task or a BSG as competition without personal involvement, because of the high complexity management game time and investment necessary to facilitate the process [22]. In addition, by grounding gaming activities supported by projectbased learning pedagogy, the characteristics of digital games can be in line with the intended objectives of education and thus facilitate the achievement of their [23]. Kulkarni state that [19] most business simulation enable student to manage a firm in competitive environment; (1) compete with other firm in the same industry, (2) produce, manage resource and market goods to achieve profit, (3) Each team compete each other and require to run the firm by deciding across functional area (marketing, R\&D, HR, manufacturing, finance). Simulation create role play by student to act as new character in business area. Business simulations content give a range of learning as an outcome and also developing knowledge, at the same time developed skills after playing the simulation game [24]. In Juan Sebastián and Carlos Mario, view that simulation game is an active learning approach for teaching strategies [25]. According to Tawil, the simulation game provide understanding to decision making that is involved in business life and the effective of a real business [26].

\section{Methodology}

Quantitative designs adapt from [27-28] were used to find which of the elemen of business simulation that facilitate of business plan preparation and the relationship among them. Students of entrepreneurship courses (114 students) were selected to run business simulation play testing. Students were instructed to play business simulation using computer-based simulation. Before they run the business simulation they need to answer questionnaire of pre-session after playing the business simulation they need to answer a post-session of questionnaire. The objective of the questionnaire was to evaluate the perceptions of the students [22, 29] towards business simulation games to facilitate business plan learning and its impact between traditional method and after using simulation.

\subsection{Sampling}

The sample for this study is Entrepreneurship Course students from Bachelor Degree program and Diploma program. The simulation game is Business Plan Game that use Visual Basic for Application (VBA) in Microsoft Excel. This game designed to create simulation business process that follow requirement of Malaysian business entity development. The business simulation game still in prototype mode and will be update after analyze the feedback from the player.

\subsection{Measurement}

Students were needed to answer a set of pre-test and post-test questionnaire. The measurements were adapted from the works of [30-32]. The questionnaire is divided into 3 sections. Section 1 comprises background and sosio-demographic of student's education and experiences, Section 2 is to assess the traditional method of learning business plan. Section 3 is to test the factor of simulation that facilitate business plan learning. Measurements in section 2 and 3 were based on 5 point Likert scale from highly ineffective strongly disagree to highly effective strongly agree.

\subsection{Background of the Business Simulation}

The business simulation is design to assist student for make business plan preparation. In other word that this simulation focus on the business setup process, and strategical planning of business function area. The development of this business simulation using Microsoft excel VBA (Visual Basic for Operation) [33]. In this simulation player can play alone or in group [28]. This simulation require player to set up a company, capital, manage resource and manage financial. Player need to carefully determine the allocation of expenses and capital that need to run the business (see Figure 2). Basically, in this simulation it has already put 3 default businesses that the player can choose. The business that set default in the simulation is Small Medium Enterprise (IKS) production like 
Starfruit Juice and Catfish Cracker. The Simulation have four-part Administration, Marketing, Operation and Financial. This simulation allows student or participant to understand the process of starting business before they can convert it into strategical business planning.

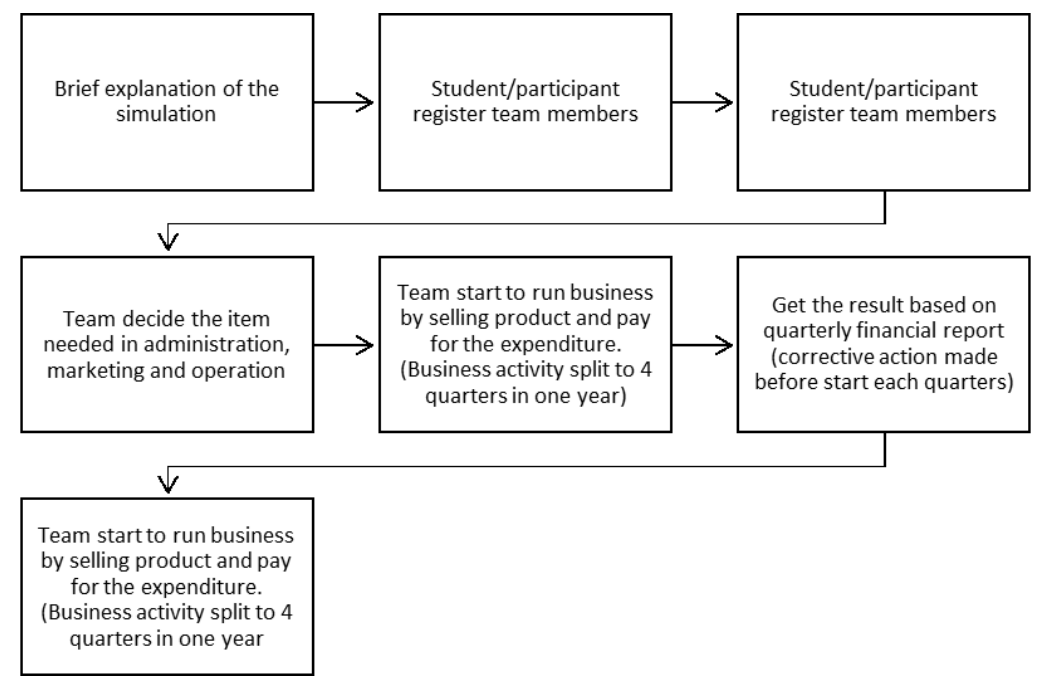

Fig 2. Flow chart of the business plan simulation

\section{Results and Analysis}

\subsection{Respondent Background}

The frequencies analysis shows that most of the participant were female $74.5 \%$ instead of male only $25.4 \%$ and most of them were 20-25 years old. From the analysis, also there are $43 \%$ of management student that involve in preparing business plan of entrepreneurship. $38 \%$ of them also are from the matriculation program and about $42 \%$ of the participant get $71.9 \%$ score CGPA 3.0 and above. 114 participants agree that the business plan is a crucial part in entrepreneurship education. $29 \%$ of the participant state that lecture is the traditional way to learn business plan. Before the simulation session begin $80.7 \%$ of them decide that the traditional method is effective of learning business plan, however $93 \%$ of them interested of using business simulation method in learning business plan.

\subsection{Student's Characteristic}

Student characteristics is one of the factor that can facilitate business plan learning through playing simulation[34-35]. Its show that how can the characteristic of the student give impact to the learning and how they can shift or upgrade their skill and knowledge from experiencing the business simulation. It is including writing skills, decision making, problem solving etc. Gain new knowledge and ability to recognize the problem show high score of percentage that the participant agreed. Following are the feedback from questionnaire that show student characteristic gain from simulation towards effective business plan.
Table 1. Characteristic of Student (Skills and Knowledge)

\begin{tabular}{lc}
\hline \multicolumn{1}{c}{ Items } & Agree \% \\
\hline Help to increase ability to write business plan & 84.2 \\
Increase ability to seek for information & 82.5 \\
Learn of make decision from various sources & 80.7 \\
Gain more knowledge of business plan & 80.7 \\
Increase ability to make business decision & 82.4 \\
Increase ability to recognize business problem & 78.0 \\
Increase skills and knowledge of real business & 76.3 \\
Increase potential of planning business & 83.3 \\
competencies & 78.0 \\
Increase problem solving skills & 89.5 \\
Gain new business knowledge & 86.9 \\
Integrating various functional business &
\end{tabular}

\subsection{Educator's Roles}

Educator like teacher, instructor and lecturer are involving in delivering the knowledge [36-37]. The simulation itself might be not complete enough if the educator not involve. The human capital of delivering knowledge still relevant enough this day even though we are surrounding by the technologies. In this result show that student need the assistant from the educator even though they choose to have own group and read the simulation manual. Explanation from the lecturer show high score of percentage level of agree from the student. Following are the feedback from questionnaire that show educator roles that take part of simulation towards effective business plan. 
Table 2. Educator's Roles

\begin{tabular}{lc}
\hline \multicolumn{1}{c}{ Items } & $\begin{array}{c}\text { Agree } \\
\mathbf{\%}\end{array}$ \\
\hline $\begin{array}{l}\text { It's hard to run the simulation without clear } \\
\text { explanation from the lecturer }\end{array}$ & 71.1 \\
$\begin{array}{l}\text { Information given from the lecturer not enough to } \\
\text { run the simulation }\end{array}$ & 38.6 \\
$\begin{array}{l}\text { The simulation's manual need to be distribute } \\
\text { before beginning the simulation }\end{array}$ & 70.1 \\
$\begin{array}{l}\text { The student need more times to read the manuals } \\
\text { The group must be selected by the lecturer }\end{array}$ & 73.7 \\
$\begin{array}{l}\text { Student need to have a right to choose their own } \\
\text { teams members }\end{array}$ & 41.2 \\
$\begin{array}{l}\text { Lecturer need to be always monitoring and give } \\
\text { response every single time }\end{array}$ & 81.6 \\
$\begin{array}{l}\text { Student need to give their freedom on running the } \\
\text { simulation without the lecturer around }\end{array}$ & 43.0
\end{tabular}

\subsection{Simulation Game Characteristics}

Previous analysis shows the side factor that effecting the simulation process however the simulation itself is the most important thing that will prove either the simulation working or not to facilitate the business plan learning [38]. The element that contain in the simulation need to be in the right place time and for the right person. As show on the analysis below, student agree that the simulation meet the requirement of business plan preparation and give them the real business experiences. However, most of them not really understand the term and condition of the simulation, they also agree that the time given is not enough and hard to work in group due to that issue. Following are the feedback from questionnaire that show simulation game characteristic towards facilitating effective business plan:

Table 3. Simulation Game's Characteristics

\begin{tabular}{lc}
\hline \multicolumn{1}{c}{ Items } & $\begin{array}{c}\text { Agree } \\
\%\end{array}$ \\
\hline $\begin{array}{l}\text { It's hard to understand the simulation term and } \\
\text { condition }\end{array}$ & 38.6 \\
$\begin{array}{l}\text { The information on the manual not help enough } \\
\text { I don't really familiar with the default business }\end{array}$ & 38.5 \\
in this simulation & 51.8 \\
$\begin{array}{l}\text { The turnover time of this simulation take too } \\
\text { much longer }\end{array}$ & 41.2 \\
$\begin{array}{l}\text { The default business in this simulation is meet } \\
\text { the business plan requirement }\end{array}$ & 72.8 \\
$\begin{array}{l}\text { The simulation gives us the real business } \\
\text { experiences }\end{array}$ & 74.5 \\
$\begin{array}{l}\text { The time given to run this simulation is not } \\
\text { enough }\end{array}$ & 52.7 \\
$\begin{array}{l}\text { This business simulation is design for individual } \\
\text { not for the group }\end{array}$ & 46.5 \\
$\begin{array}{l}\text { It's hard to work within the group due to lack of } \\
\text { time and sources }\end{array}$ & 41.2
\end{tabular}

Student need to have one-week preparation before run the simulation The rating and marks of the simulation distribute properly

\subsection{Infrastructures}

The infrastructure provide in the classroom are also one of the element that will affect the process of the simulation. The infrastructures referring on the facilities that provide to ensure the process of the business simulation to run smooth. Almost all the student agree that computer aid simulation make their work in group easy and able to search for extra information before make any decision. Following are the feedback from questionnaire that show the importance of classroom infrastructure towards preparing effective business plan:

Table 4. Infrastructures

\begin{tabular}{lc}
\hline \multicolumn{1}{c}{ Items } & Agree \% \\
\hline $\begin{array}{l}\text { In class group table layout assist the process of } \\
\text { the simulation }\end{array}$ & 61.4 \\
$\begin{array}{l}\text { Internet access in classroom assist the process of } \\
\text { gathering information }\end{array}$ & 59.7 \\
$\begin{array}{l}\text { Computer slide presentation help to deliver } \\
\text { simulation information }\end{array}$ & 80.7 \\
$\begin{array}{l}\text { Ease of extension socket that enable the use of } \\
\text { laptop }\end{array}$ & 75.4 \\
$\begin{array}{l}\text { Computerize simulation helped students } \\
\text { Integrating various functional business } \\
\text { knowledge }\end{array}$ & 87.7 \\
\end{tabular}

\subsection{Experiential Learning}

Experiential Learning is the core that determine the value of the simulation. Most of the simulations in various industrial types are design to simulate the experiential learning that assist the participant to really understand the process of something using simulative environment before entering the real situation. The result of the analysis show that the business simulation gives real business experience and important to the business process. Following are the feedback from questionnaire that show the experiential learning of student towards preparing effective business plan: 
Table 5. The Experiential Learning

\begin{tabular}{lc}
\multicolumn{1}{c}{ Items } & Agree \% \\
\hline The business simulation facilitates in preparing business plan & 70.2 \\
This business simulation is user-friendly & 69.3 \\
This business simulation allows the transfer of knowledge from theory to practical & 82.5 \\
This simulation challenge and test knowledge and skills & 81.5 \\
This simulation is interesting and impressive & 79.8 \\
This simulation is relevant and useful for student & 82.5 \\
This simulation is meaningful to the learning process & 81.6 \\
This simulation run with organize order & 79.8 \\
This business simulation gives the real business experiences & 83.3 \\
Simulation is important to the business process & 83.3 \\
The simulation provides enjoyable experience & 77.2 \\
This simulation clear and easy to understand & 75.4 \\
This simulation is difficult and bored & 50.9 \\
This simulation brings real business problem in classroom & 65.7 \\
The simulation helps to understand difficult business concept & 78.1
\end{tabular}

\subsection{Impact of The Simulation}

The impact of the simulation show how the simulation facilitate of business plan learning. It is also known as the complete structure of the simulation that contain the element; (1) to test student characteristic, (2) to determine the role of the educator, (3) of the mechanic for game characteristic, (4) that need facilities that provide ease of usage and (5) of experiential learning that can be found during and after playing simulation. The high score of percentage from the analysis show that the simulation facilitates the student to make business decision and they able to integrate all offbusiness function. Following are the feedback from questionnaire that show the impact of business simulation in preparing effective business plan:

Table 6. The Impact of Business Simulation

\begin{tabular}{lc}
\multicolumn{1}{c}{ Items } & $\begin{array}{c}\text { Agree } \\
\%\end{array}$ \\
\hline $\begin{array}{l}\text { The simulation facilitates the student about } \\
\text { understanding business process }\end{array}$ & 79.8 \\
$\begin{array}{l}\text { The simulation enable student to integrate all of } \\
\text { business function }\end{array}$ & 85.1 \\
$\begin{array}{l}\text { The simulation facilitates the student how to make } \\
\text { business forecasting }\end{array}$ & 84.2 \\
$\begin{array}{l}\text { The simulation facilitates the student to make } \\
\text { properly business decision }\end{array}$ & 86.8 \\
$\begin{array}{l}\text { The simulation facilitates the student to distribute } \\
\text { resource according to the priorities }\end{array}$ & 83.3 \\
$\begin{array}{l}\text { The simulation facilitates the student in preparing } \\
\text { financial reporting }\end{array}$ & 81.6 \\
$\begin{array}{l}\text { The simulation facilitates the student on how to } \\
\text { implement marketing strategies }\end{array}$ & 82.5 \\
$\begin{array}{l}\text { The simulation facilitates the student to explore } \\
\text { operational aspect in business }\end{array}$ & 85.1 \\
$\begin{array}{l}\text { The simulation facilitates the student on how to } \\
\text { evaluate the elements of cost saving. }\end{array}$ & 83.4
\end{tabular}

\subsection{The Importance of Business Simulation}

This analysis also tries to find the most important aspect in business simulation. From below data shows that the first important thing is Encourage of Cooperation followed by Realistic Content of Business

World, Individual Interaction, Joy and Excitement and then the last one is Educational Value. Following are the feedback from questionnaire that show the importance of business simulation in preparing effective business plan:

Table 7. The Importance of Business Simulation

\begin{tabular}{lc}
\hline \multicolumn{1}{c}{ Items } & Important \% \\
& \\
\hline Individual Interaction & 84.2 \\
Realistic content of business world & 86.8 \\
Encourage of cooperation & 92.1 \\
Joy and excitement & 84.2 \\
Educational Value & 83.3
\end{tabular}

\subsection{The Simulation's Factor That Facilitate Business Plan Learning}

The student also gives responses to factor that facilitate the business plan learning. The four factor of developing business plan are (1) Student acceptance (Student Characteristic on cognitive and affective domain), (2) The Simulation's content (Simulation Game Mechanic and Characteristic) (3) Lecturer role (Delivering and facilitating) (4) Infrastructure and technical aid. From the simulation factor the Lecturer 'roles show $82.5 \%$ influence to facilitate business plan learning. Following are the feedback from questionnaire that show the impact of business simulation in preparing effective business plan:

Table 8. The Influence of Simulation factor to facilitate business plan learning

\begin{tabular}{lc}
\hline \multicolumn{1}{c}{ Items } & Influence \% \\
\hline Student Acceptance & 68.4 \\
The content of Simulation & 76.4 \\
Educator's Role & 82.5 \\
Infrastructure and technical aid & 80.7
\end{tabular}




\subsection{Statistical Result of Regression Analysis}

The statistical measure using regression analysis show that the R Square from the model summary is .617 are close to 1 . This indicate that the value of the variance to the score of Business Simulation (DV) that is associated with the independence variable (infrastructure, educator's roles, student characteristic, the content of the game and experiential learning) is $61.7 \%$ as showed in table 9. The value in table 10 ANOVA show that this model with R square $61.7 \%$ is significant, when $\mathrm{p}<.05$.

Table 9. Model Summary

\begin{tabular}{|c|c|c|c|c|}
\hline Model & $\mathbf{R}$ & $\begin{array}{c}\mathbf{R} \\
\text { Square }\end{array}$ & $\begin{array}{c}\text { Adjusted R } \\
\text { Square }\end{array}$ & $\begin{array}{c}\text { Std. Error of the } \\
\text { Estimate }\end{array}$ \\
\hline 1 & $.785^{\mathrm{a}}$ & .617 & .599 & 3.42185 \\
\hline
\end{tabular}

a. Predictors: (Constant), infrastructure, educator, student, game, experiential

Table 10. ANOVA ${ }^{\mathrm{a}}$

\begin{tabular}{|c|c|c|c|c|c|}
\hline Model & $\begin{array}{c}\text { Sum of } \\
\text { Squares }\end{array}$ & df & $\begin{array}{c}\text { Mean } \\
\text { Square }\end{array}$ & F & Sig. \\
\hline 1 Regression & 2034.440 & 5 & 406.888 & 34.750 & $.000^{\mathrm{b}}$ \\
Residual & 1264.577 & 108 & 11.709 & & \\
Total & 3299.018 & 113 & & & \\
\hline
\end{tabular}

a. Dependent Variable: Business Simulation

b. Predictors: (Constant), infrastructure, educator, student, game, experiential

As refer to the Table 11, the beta value indicates that small contribution of $.150(15 \%)$ from educator. Meanwhile the highest contribution of .340 (34\%) si from the score of student characteristic as significantly influence the score of business simulation, after the others contribution in the control model.

Table 11. Coefficients ${ }^{\mathrm{a}}$

\begin{tabular}{|l|l|l|l|l|l|}
\hline \multirow{4}{*}{ Model } & \multicolumn{2}{|l|}{$\begin{array}{l}\text { Unstandardized } \\
\text { Coefficients }\end{array}$} & $\begin{array}{l}\text { Standardized } \\
\text { Coefficients }\end{array}$ & & \\
\cline { 2 - 5 } & \multicolumn{1}{|l|}{ B } & $\begin{array}{l}\text { Std. } \\
\text { Error }\end{array}$ & Beta & t & Sig. \\
\hline 1(Constant) & 6.780 & 2.613 & & 2.594 & .011 \\
game & .105 & .063 & .150 & 1.672 & .097 \\
student & .280 & .078 & .340 & 3.581 & .001 \\
educator & -.208 & .095 & -.193 & -2.184 & .031 \\
experiential & .211 & .074 & .289 & 2.847 & .005 \\
infrastructure & .438 & .107 & .298 & 4.092 & .000 \\
\hline
\end{tabular}

a. Dependent Variable: Business Simulation

This regression equation carry the meaning of the Business Simulation predict base on following equation: Business Simulation score $=.105$ (game $)+.280($ student $)+.208($ educator $)+.211($ experiential $)+.438$ (infrastructure $)+6.780$. Student score $($ Beta $=.340, \mathrm{p}, .05$ are the best predictor that significant as compare to another score with the overall of R square .617 .

\section{Finding and Discussion}

This study finds that the most facilitate factor that contribute to the development of business simulation is the student characteristic including their knowledge, experience, expectancies, motivation and their affective and cognitive level. As mention from Kadot study the simulation allow student to test their current knowledge and make decision based on the resource that been distribute in the simulation [39]. It shows that the experiential learning by running simulation to facilitate the learning of business plan is helpful to the student while they apply and their knowledge from theory knowledge to be implement in the simulate real business world. Student take decisions across business functional areas when they compete each other to run the firm and defined the decision cycles [19]. They by themselves for the same time will increase their motivation to take care of the business by carefully made decision and motivate them to be the best with proper management. Because every simulation is the same that need input from student to process information and face other participants with certain outcome of decision [18]. This knowledge and skills that gain from playing the simulation make them ready to write the business plan properly with considering the element of integrate business function and understanding the basic business process. Even the element of student characteristic is the most facilitate, this study also agrees that the others element such experiential and educator's role somehow contribute to the successful of business plan simulation. While for the infrastructure that provide by the trainer is known as the element of assisting the progress of the simulation that depend on the present facilities and physical ease. Respond on the element that less contribute to the simulation, it is need some improvement to the content that in other word is try to match the current situation and be more user friendly and put extra mechanic of the simulation. Business plan simulation prove to be effective factor that help student to prepare well before writing the business plan because after playing they have gain to improvise and increase their knowledge, skill and confident level to understanding the way how business will be set up.

\section{Conclusion}

Preparing effective business plan are the key to gain financial assistant for graduate to start a business as their career. To make it effective student need to know better the process of business, to understand the process they need to run the business. Running business in simulated environment minimizing risk and can restart over to analyze the problem. However, we suggest that in future research to create a business 
simulation that enable student to run business with real product and real market approach.

1. A. Chwolka, M.G. Raith, J. Bus. Ven., 27(3), 385399 (2012)

2. J. Brinckmann, D. Grichnik, Kapsa, J. Bus. Ven., 25(1), 24-40 (2010)

3. B. Honig, Aca. Man. Learn. Edu., 3(3), 258-273. (2004)

4. B. Honig, T. Karlsson, Admin. Sc., 3(4), 266-289 (2013)

5. C. Bianchi, G. W. Winch, C. Grey, Proceedings of the 16th International Conference of the System Dynamics Society, Quebec '98, 1(c), 21 (1998)

6. T. Y. Nian, R. Bakar, A. Islam, A, Students ' Perception on Entrepreneurship Education: The Case of Universiti Malaysia Perlis, 7(10), 40-49 (2014)

7. E. Auchter, M. Keding, BRIDGING THE GAP: Transforming Knowledge into Action through Gaming and Simulation. Proceedings of the 35th Conference of the International Simulation and Gaming Association, Munich, 2004)

8. M. Z. Ismail, S. Z. Ahmad, J. Chinese Entrep., 5, 144-160 (2013)

9. Z. Arasti, M. Kiani Falavarjani, N. Imanipour, Hi. Edu. Stud., 2(1), 2-10 (2012)

10. C. Elgood, How Do You Create Effective Business Simulation Games? Elgood' S 10 Step Design Process Tackle Your Issues • Engage Your Staff • Maximise Performance How Do You Create Effective Business Simulation Games? Elgood Effective Learning. (2011)

11. C. M. Mason, J. M. Stark, Int. S. Bus. J., 227-248 (2013)

12. L. Pittaway, a, Simulating Entrepreneurial Learning: Assessing the Utility of Experiential Learning Design, (2004)

13. A. Y. Kolb, D. H. Kolb, Man. Learn., Edu. Dev., 1-59 (2008)

14. J. A. Poore, D. L. Cullen, G. L. Schaar, Clinic. Sim. Nur., 10(5), 241-247 (2014)

15. S. Dellaportas, T. Hassall, Brit. Acct. Rev, 45(1), 24-36 (2013)

16. A. Ayob, A. Hussain, M.M. Mustaf, M.F.A. Shazi Shaarani,., Proc. - Soc. Behav. Sc., 18, 247-254 (2011)

17. D. Finch, M. Peacock, D. Lazdowski, M. Hwang, Int. J. Man. Edu., 13(1), 23-36 (2015)

18. D. Keshodarah, Capacity Building in Entrepreneurship Education and Training Using Simulation. In: International HRD Conference, Mauritius 2013: Excellence in HRD for sustainable growth Capacity, 1-12 (2013)

19. B. Kulkarni, Using Business Simulations To Introduce Business Concepts, 40, 393-400 (2013)

20. R.S. Mulcahy, Int. J. D. Learn., 2, 1-17 (2011)

\section{References}

21. M. Critelli, D. I. Schwartz, S. Gold, Serious Social Games: Designing a Business Simulation Game. 4th International IEEE Consumer Electronic Society - Games Innovation Conference, IGiC 2012, 2-5 (2012)

22. Y. Tao, C. Cheng, S. Sun, Edu. Techno. Soc., 15, 177-189 (2012)

23. H. Panoutsopoulos, M. A. Lykourentzou, D. G. Sampson, Business Simulation Games as Digital Tools for Supporting School Entrepreneurship Education. Proceedings of the 2011 11th IEEE International Conference on Advanced Learning Technologies, ICALT 2011, 155-156 (2011)

24. A F. Barišić, P. Monika, Business Simulation as a Tool for Entrepreneurial Learning The Role of Business Simulation in Entrepreneurship Education. In: 4th International Conference on Entrepreneurial Learning 2014 - ICEL4, (Cmc) (2014)

25. J. Sebastián, C. Mario, Dev. Bus. Simu. Exp. Learn., 42(2015), 117-123 (2015)

26. N. M. Tawil, R. Hassan, S. Ramlee, Z. K-Batcha, Journal of Engineering Science and Technology, 10 (Spec. Issue on 4th International Technical Conference (ITC) 2014), 71-80 (2015)

27. L. Vos, R. Brennan, Marketing Simulation Games: Student and Lecturer Perspectives (2010)

28. N.L. Abdullah, M.H. Hanafiah, N. A. Hashim, Int. Edu. Stud., 6(6), 95-107 (2013)

29. T. Russ, M. Drury-Grogan, Comm. Quart., 61(5), 584-595 (2013)

30. C.N. Bodea, R. I. Mogo, M. I. Dasc, A. Purnu, N.G. Ciobotar, Amfit. Eco. 17(38),10-24 (2015)

31. W. J. Wellington, D. Hutchinson, M. Gowing, 38, 320-326 (2011)

32. S. Shane, E. Locke, C. J. Collins, Human Res. Man. Rev., 13, 257-279 (2003)

33. Evans, INFORMS Trans. Edu., 1, 27-37 (2000)

34. B. Baruah, A. Ward, Enhancing Intrapreneurial Skills of Students through Entrepreneurship Education. ITHET 2014 - 13th International Conference on Information Technology Based Higher Education and Training. (2015)

35. W. Wellington, and Hutchinson, D., Dev. Bus. Simu. Exp. Learn., 39, 132-140 (2012)

36. J. Moizer, J. Lean, M. Towler, G. Smith, Int. J. Learn. Techno., 2(1), 49 (2006)

37. P. H. Anderson, L. Lawton, L, Simu. Gam., 40, 193-216 (2008)

38. W. M. P. Aalst, Van Der, In: J. vom B. (5) and M. Rosemann, eds., Handbook on Business Process Management 1, (Part II., Springer Berlin Heidelberg, 1-34, 2015) 
39. E. Cadotte, Ann. Entrep. Edu. Peda, 280-301

(2014) 